\title{
Performance of Some Promising Rust Resistant Bread Wheat Genotypes Under Rain-fed Conditions
}

\author{
Emad M. Al-Maaroof*, Sayran S. Hassan, Parez A. Taha, Peshawa H. Said, Soma I. Aziz
}

Biotechnology and Crop Science Department, College of Agricultural Engineering Sciences, University of Sulaimani, Sulaimai, Iraq(emad.ghalib@univsul.edu.iq, sayran.hasan@univsul.edu.iq,parez.taha@univsul.edu.iq,peshawa2012@yahoo.com, Somaaziz93@yahoo.com)

*Correspondence: emad.ghalib@univsul.edu.iq

\begin{abstract}
The current study was conducted to evaluate the performance and behavior of eight promising wheat genotypes produced by different breeding programs as comparing with the local wheat cultivars under rain-fed conditions at the experimental field of the College of Agricultural Engineering Sciences, University of Sulaimani in Bakrajo during two crop seasons 2014 to 2016. The experiments were laid out according to a randomized complete block design with three replications. Seeds were cultivated at a rate of $140 \mathrm{~kg} / \mathrm{ha}$ in rows within plots. Host reactions of the tested genotypes with the pathogen population of Puccinia striiformis $\mathrm{f}$. sp. tritici were also investigated under natural infection conditions at the same field. Results revealed high significant differences among the genotypes in term of all the studied traits. Charmo significantly surpassed all other genotypes in stem width $(4.90 \mathrm{~mm})$, number of kernels per spike (58.41) and grain yield $\left(3856.06 \mathrm{~kg} \mathrm{~h}^{-1}\right)$, the higher value of grain weight $(46.59 \mathrm{~g})$ was detected in Azmar 2, while the higher amount of spike per square meter (586.6 spike) was produced by the genotype Shaho2. Azmar2 significantly surpassed all other genotypes in spike length $(12.7 \mathrm{~cm})$ and leaf area $\left(48.51 \mathrm{~cm}^{2}\right)$ while the highest plant height $(110.1 \mathrm{~cm})$ was detected in Maaroof. Based on the disease severity and coefficient of infection of the genotypes to yellow rust disease, Maaroof, Shaho and Azmar explored high disease resistance reaction and coefficient of infection, while SaberBeg, Aras and Adana showed high susceptibility to the disease.
\end{abstract}

Keywords: Triticum aestivum, Fungal diseases, Wheat Rust, Resistant Cultivars, Yield Potential

Received: June $1^{\text {st }}, 2020 /$ Accepted: August $20^{\text {th }}, 2020 /$ Online: September $12^{\text {th }}, 2020$

\section{INTRODUCTION}

Wheat (Triticum aestivum L.) is the most important staple food of about $36 \%$ of the world population. It provides more than $20 \%$ of the food calories and protein consumed globally (Hawkesford et al., 2013). Wheat is an edible grain cultivated in a wide range of climates and soils. ; It is ideally suited to temperate rainfall areas ranging from 300 to 900 $\mathrm{ml}$ (FAO, 2003). Most of the current cultivars are hexaploid wheat, known as bread or hard wheat and valued for making various kinds of bread. Wheat grown in dry climates is typically hard form, with a protein content of 11-15 per cent and a high gluten content. Wetland wheat is softer, with 8$10 \%$ protein content and low gluten. The softer variety provides flour that is ideal for pastry, cookies, crackers, cakes, and household flours. The majority of grown wheat is used for human consumption and about ten percent is kept for seed and industry. Wheat grain contains all the necessary nutrients, water $12 \%$, carbohydrates mainly as starch (60$8 \%$ ), proteins rich with all the important amino acids except lysine, tryptophan and methionine (8-15\%), fats (1.5-2\%), minerals $(1.5-2 \%)$, vitamins mainly $\mathrm{B}$ complex and $\mathrm{E}$ and crude fibers $2.2 \%$ (MacRitchie, 1987).

Wheat lands in Iraq are divided into irrigated and rain fed zones. Rain-fed lands are primarily situated in the north. Wheat production is optimal in the irrigated areas, however, rain-fed areas account for less wheat production. An estimated four million tons of wheat were produced in 2018 , with a decrease of 14 per cent from 2017, mainly due to adverse environmental condition risks. Almost the equal amount of wheat grains had been introduced (FAO, 2018). Drought and salinity conditions are the major abiotic constraints of production in wheat (Ahmad et al., 2016, Ali et al., 2018, Schnepf, 2003).

Many biotic factors can attack the crop, mainly due to fungi, bacteria, and viruses. The main important wheatdiseases in Kurdistan region can be categories to seed-borne diseases like covered smut (common bunt), loose smut, and 
seed gall; airborne diseases including yellow rust, leaf blotch, stem rust and barley yellow dwarf virus disease (AlBaldawi, 1993). Breeding progams to develop new disease resistant cultivars are important for the prevention of significant crop losses due to fungal diseases, and there may be significant variable cost in the production of wheat. Estimates of annual losses in wheat production due to the diseases is ranging from 10-70\% (Al-Maaroof et al., 2001, 2005). The breeding program for disease resistance in Iraq resulted from registration and release of some new promising wheat cultivars, the main objective of the current study is to evaluate the performance and behavior of some new promising rust resistant wheat genotypes as comparing with the local wheat cultivars under rain-fed conditions at the experimental field station of the College of Agricultural Engineering Sciences, University of Sulaimani, IKR, Iraq.

\section{MATERIALS AND METHODS}

\section{A. Study location}

The current study was conducted to evaluate performance and behavior of eight promising resistant wheat genotypes (HSAD, Bakrajo139, Shaho2, Azmar2, Alaa, Maaroof, Alwand, and Charmo) as comparing with the local wheat cultivar (Aras) and Adana at the experimental field station of the College of Agricultural Engineering Sciences, University of Sulaimani in Bakrajo (Latitude N $35^{\circ} 32$ 036; Longitude E $45^{\circ} 21865$ and Elevation 726m) 10km south west of Sulaimani center during the crop seasons of 20142016. Sowing date was November 12th and 20th, 2014 and 2015, respectively. Some physical and chemical characteristics of the experiment location soil are illustrated in Table 1. Air temperature and rainfall during the growing seasons of 2014/15 and 2015/16 at Bakrajo station was shown in Table 2.

\section{B. Experimental design}

The field experiments were designed according to Randomized Complete Block Design (RCBD) with three replications. The experimental units were with an area of $25 \mathrm{~m}^{2}(5 \times 5)$ randomly distributed in each block. The land of the experiment was prepared by plowing the field twice using mold board plow and harrowed by a disk, wheat seeds were obtained from the breeding program of improving disease resistance in wheat to the main wheat diseases, cultivated at $(140 \mathrm{~kg} / \mathrm{ha})$ seed rate in rows and $30 \mathrm{~cm}$ of row intervals within the plots. The distance between row to row was $30 \mathrm{~cm}$ DAP fertilizer ( $46 \% \mathrm{P}, 18 \% \mathrm{~N}$ ) was added to the soil at sowing with the recommended dose of $\left(160 \mathrm{Kg} \mathrm{ha}^{-1}\right)$, and Nitrogen Fertilizer as a form of Urea $(46 \% \mathrm{~N})$ was applied twice at sowing and at the beginning of tillering with the amount $63 \mathrm{~kg} \mathrm{ha}^{-1}$ and $130 \mathrm{~kg} \mathrm{ha}^{-1}$, respectively, all the agricultural practices were conducted as recommended.
Table 1. Some physical and chemical characteristics based on soil analysis of the experimental field station results. College of Agricultural Engineering Sciences.

\begin{tabular}{lc}
\hline Soil properties & Values \\
\hline Soil texture $($ P.S.D) & Silty Clay \\
\hline Sand $(\mathrm{g} / \mathrm{kg})$ & 48.5 \\
\hline Silt $(\mathrm{g} / \mathrm{kg})$ & 449.8 \\
\hline Clay $(\mathrm{g} / \mathrm{kg})$ & 501.7 \\
\hline E.C. $(\mathrm{dS} / \mathrm{m})$ & 0.33 \\
\hline $\mathrm{pH}$ & 7.44 \\
\hline $\mathrm{O} . \mathrm{M} .(\mathrm{g} / \mathrm{kg})$ & 21.02 \\
\hline $\mathrm{CaCO} 3(\mathrm{~g} / \mathrm{kg})$ & 337.6 \\
\hline Total $\mathrm{N}(\mathrm{ppm})$ & 19.93 \\
\hline $\mathrm{K}+(\mathrm{g} / \mathrm{kg}-)$ & 2.67 \\
\hline $\mathrm{Na}+(\mathrm{ppm})$ & 27.66 \\
\hline $\mathrm{Ca}^{++}(\mathrm{Meq} / \mathrm{l})$ & 2.66 \\
\hline $\mathrm{Mg}^{++}(\mathrm{Meq} / \mathrm{l})$ & 1.98 \\
\hline
\end{tabular}

Table 2. Average air temperature and rainfall during the growing seasons of 2014 to 2016 at Bakrajo Metrological Station, Sulaimani, IKR, Iraq.

\begin{tabular}{ccccccc}
\hline & \multicolumn{3}{c}{ Average Air Temperature $\left({ }^{\circ} \mathrm{C}\right)$} & \multicolumn{2}{c}{ Rainfall $(\mathrm{mm})$} \\
\cline { 2 - 6 } Months & \multicolumn{2}{c}{ Max. } & \multicolumn{2}{c}{ Min. } & & \\
\cline { 2 - 6 } & $2014 / 15$ & $2015 / 16$ & $2014 / 15$ & $2015 / 16$ & $2014 / 15$ & $2015 / 16$ \\
\hline \multirow{2}{*}{ November } & 22.2 & 21.3 & 2.9 & 7.6 & 130.4 & 44.5 \\
& & & & & & \\
\hline December & 17.9 & 11.1 & 2.2 & 3.0 & 115.3 & 158.0 \\
\hline January & 16.6 & 11.10 & 3.2 & 1.46 & 99.6 & 59.2 \\
\hline February & 19.8 & 13.02 & 0.2 & 0.26 & 67.6 & 96.5 \\
\hline March & 22 & 17.73 & 3.2 & 7.45 & 101.8 & 111.5 \\
\hline April & 32.2 & 23.89 & 5.0 & 10.97 & 23.5 & 54.5 \\
\hline May & 36.9 & 31.63 & 11.2 & 13.48 & 17.2 & 27.7 \\
\hline Total & & & & & & \\
\hline
\end{tabular}

\section{Disease scoring and data analysis}

Infection types and disease severities were assessed at different wheat growth stages using Lewellen score, where Zero $=$ No visible symptoms; $\mathrm{R}=$ Resistant, Necrosis with or without small pustules; $M R=$ moderately resistant, small pustules surrounded by necrosis, $\mathrm{M}=$ intermediate, variable size pustules with necrosis or chlorosis; MS= Moderately susceptible, medium sized pustules, some chlorosis possible without necrosis, $\mathrm{S}=$ Susceptible, large size pustules without chlorosis or necrosis (Lewellen et al., 1967). While disease severities were calculated using modified Cobb scale (Peterson et al., 1949), which depends on comparing the infected wheat leaves with the theoretical diagram showing the frequency of uredia for particular percentage disease severity. Data were randomly collected from 30 plants in each plot.

Yellow rust coefficient of infection (C.I) was calculated on each cultivar by multiplying the severity times with a constant values of host response, where immune $(\mathrm{I})=0.00$, $(\mathrm{R})=0.20,(\mathrm{MR})=0.40,(\mathrm{M})=0.60,(\mathrm{MS})=0.80$, and $(\mathrm{S})=$ 
1.00. This makes it easy to rank or statistically comparison between genotypes or nurseries (Roelfs et al., 1992).

C.I $=$ DS * IT, where $(\mathrm{DS})$ is Disease severity and $(\mathrm{IT})=$ Infection type.

\section{Agronomic traits}

Data on agronomic traits were recorded as in usual as follows; Plant height measured at physiological maturity from the soil surface to the top of the plant including spike without the awn as a mean of ten random plants in each experimental unit. Flag leaf area was calculated in centimeter square after anthesis stage by measuring the mean of the flag leaf area from 10 plant randomly taken from the center lines of each experimental unit as shown below.

Leaf area $=$ maximum length $\times$ maximum width $\times 0.95$ (Chanda and Singh, 2002).

Stem width of the main stem of each genotype was measured at the base of the plant by using Vernier equipment, mean of 10 plants from the center lines were used from each plot, Spike length of the main spikes of the selected plants excluding awn was measured at maturity in centimeters, Awn length of the selected spikes were measured from the end of spike to the end of awn in centimeters by ruler (Alam et al., 2007).

\section{E. Yield components}

Number of spikes was counted for an area of one square meter from the center of each plot. Average spike weight was calculated from fifty randomly selected spikes of each plot at the dough stage, 1000 kernel weight was measured using sensitive electronic balance. The average kernels weight of each spike was recorded by calculating kernels weight in randomly 50 selected spikes then converted to 1000 kernels weight. Average number of kernels per spike was recorded by counting the average number of kernels of 50 randomly selected spikes for each experimental plot. Grain yield of each cultivar was calculated by random harvesting of plant spikes in one square meter from the center of each plot at dough stage when the grain moisture was $14 \%$. The harvested spikes were thrashed and the grain weight per each meter was converted to (ton $\left.\mathrm{h}^{-1}\right)$ (Bell and Fischer 1994).

\section{F. Statistical analysis}

All data variance were analyzed statistically (ANOVA) at the probability level of $\mathrm{p}=0.05$. The least significant differences (L.S.D) at 5\% level were used to compare between the means of traits.

\section{RESULTS}

\section{A. Host response of wheat genotypes to Puccinia striiformis}

Table 3 shows wide ranges of host reaction between the tested genotypes and the pathogen population of $P$. striiformis from high resistance reactions in cv Maaroof, Shaho2 and Azmar2 to high susceptible in cv SaberBeg, susceptible in Aras and Adana, moderately susceptible in HSAD, moderately resistance in Alaa and Alwand, and resistant to moderately resistant in Charmo and Bakrajo139. Table 3 also shows that there are high significant differences between the tasted genotypes in infection coefficient (C.I). The highest mean value (C.I) was recorded in SaberBeg (87.8) followed by 65.9 in Aras, while the lowest mean value of (C.I) was recorded in Maaroof (0.5) followed by 1.0 and 1.4 in Shaho2 and Azmar2 respectively. Coefficient of infection value in SaberBeg was significantly surpassed all other genotypes. No any significant differences were detected between Maaroof, Shaho2, Azmar2, Alwand and Charmo in C.I value, (Table 3). The coefficient of infection value is usually used in statistical comparison between genotypes with diverse responses to the disease. Combining two separate factors in a single value results in almost equal coefficient but different disease scores.

\section{B. Agronomic traits}

Results of Table 4 represent the means of some agronomic traits of the studied genotypes, Variance analysis indicated the presence of significant differences among the genotypes in plant height, the maximum value of plant height was detected in Maaroof, which was $110.1 \mathrm{~cm}$, and significantly exceed all other cultivars except Charmo $108.5 \mathrm{~cm}$, while the lowest value of plant height was recorded on both genotypes Bakrajo139 and Aras which were 91.5 and $95.7 \mathrm{~cm}$ respectively. Differences in plant height among the genotypes may refer to the variation in their genetic background that affect their response to the available environmental conditions particularly light, temperature and development of the pants. Plant height is an important morphological trait, which is directly related to lodging and epidemic development of different airborne diseases; also it is linked with the productivity potential of the plants, this result is in agreement of any previous researcher findings (Reza and Amri 2013).

Statistical analysis results also refer to the significant effect of the genotypes on spike length trait, the highest mean value of spike length $(12.7 \mathrm{~cm})$ was detected in Azmar2, which is significantly surpassed all other cultivars except Alwand

$(12.6 \mathrm{~cm})$. 
Table 3. Coefficient of infections, Disease severity and infection types of different wheat genotypes with yellow rust disease compared with the local cultivars during the epidemics of 2015 to 2016.

\begin{tabular}{|c|c|c|c|c|c|c|c|c|c|}
\hline \multirow[t]{2}{*}{ Genotype } & \multicolumn{3}{|l|}{ IT } & \multicolumn{3}{|l|}{$\mathrm{DS} \%$} & \multicolumn{3}{|l|}{$\mathrm{CI}$} \\
\hline & 2015 & 2016 & Mean & 2015 & 2016 & Mean & 2015 & 2016 & Mean \\
\hline Hsad & MS & MS & MS & 15.0 & 33.6 & 24.3 & 12.0 & 26.9 & 19.4 \\
\hline Bakrajo 139 & MR & RMR & RMR & 10.0 & 5.0 & 7.5 & 4.0 & 1.5 & 2.3 \\
\hline Shaho 2 & $\mathrm{R}$ & $\mathrm{R}$ & $\mathrm{R}$ & 5.0 & 5.0 & 5.0 & 1.0 & 1.0 & 1.0 \\
\hline Azmar 2 & $\mathrm{R}$ & $\mathrm{R}$ & $\mathrm{R}$ & 10.0 & 5.0 & 7.5 & 2.0 & 1.0 & 1.4 \\
\hline Alaa & MR & MR & MR & 15.0 & 10 & 12.5 & 6.0 & 4.0 & 5.0 \\
\hline Maaroof & $\mathrm{R}$ & $\mathrm{R}$ & $\mathrm{R}$ & 5.0 & 0.0 & 2.5 & 1.0 & 0.0 & 0.5 \\
\hline Alwand & MR & MR & MR & 5.0 & 5.0 & 5.0 & 2.0 & 2.0 & 2.0 \\
\hline Charmo & MR & $\mathrm{R}$ & RMR & 8.5 & 5.3 & 6.9 & 3.4 & 1.1 & 2.1 \\
\hline Adana & $\mathrm{S}$ & $\mathrm{S}$ & $\mathrm{S}$ & 43.6 & 36.5 & 40.1 & 43.6 & 36.5 & 40.1 \\
\hline Aras & $\mathrm{S}$ & $\mathrm{S}$ & $\mathrm{S}$ & 77.7 & 54.0 & 65.9 & 77.7 & 54.0 & 65.9 \\
\hline SaberBeg & HS & HS & HS & 90.0 & 85.6 & 87.8 & 90.0 & 85.6 & 87.8 \\
\hline Mean & - & - & & 25.9 & 22.3 & 24.1 & 22.1 & 19.4 & 20.7 \\
\hline LSD 0.05 & & & & 6.3 & 4.5 & 5.1 & 4.3 & 3.6 & 3.5 \\
\hline
\end{tabular}

1. Infection Types (IT) were measured according to Lewellen scale (Lewellen et al. 1967).

2. Coefficient of infections (CI) were calculated according to Roelfs (Roelfs et al. 1992).

The lowest values of spike length were detected in the genotypes Bakrajo and Aras, which were 9.05 and $8.8 \mathrm{~cm}$ respectively. Spike length is considerable important character, as the large spike likely to produce more grain and eventually higher yield grain per plant.

Table 4. Agronomic traits of some promising wheat genotypes compared with the local cultivar at the field of the College of Agricultural Engineering Sciences Field, Bakrajo, Sulaimani, IKR, IRAQ during 2015/2016.

\begin{tabular}{|c|c|c|c|c|c|c|c|c|c|c|c|c|c|c|c|}
\hline \multirow[b]{2}{*}{ Genotype } & \multicolumn{3}{|c|}{ Plant Height $(\mathrm{cm})$} & \multicolumn{3}{|c|}{ Spike Length $(\mathrm{cm})$} & \multicolumn{3}{|c|}{ Awn Length $(\mathrm{cm})$} & \multicolumn{3}{|c|}{ Stem Width (mm) } & \multicolumn{3}{|c|}{ Leaf Ara $\left(\mathrm{cm}^{2}\right)$} \\
\hline & 2015 & 2016 & Mean & 2015 & 2016 & Mean & 2015 & 2016 & Mean & 2015 & 2016 & Mean & 2015 & 2016 & Mean \\
\hline HSAD & 101.3 & 108.3 & 104.5 & 10.7 & 9.8 & 10.25 & 5.3 & 5.07 & 5.18 & 3.80 & 3.49 & 3.65 & 36.80 & 36.49 & 36.65 \\
\hline Bakrajo139 & 92.4 & 90.6 & 91.5 & 9.5 & 8.5 & 9.05 & 6.1 & 4.67 & 5.38 & 3.23 & 3.07 & 3.15 & 38.48 & 37.49 & 38.15 \\
\hline Shaho 2 & 94.0 & 106.3 & 100.2 & 10.5 & 9.7 & 10.1 & 5.6 & 5.50 & 5.55 & 4.50 & 4.33 & 4.42 & 38.93 & 49.62 & 44.28 \\
\hline Azmar2 & 96.8 & 103.3 & 100.1 & 12.2 & 13.2 & 12.7 & 6.6 & 5.67 & 6.13 & 4.75 & 5.33 & 4.54 & 46.29 & 50.73 & 48.51 \\
\hline Alaa & 101.9 & 103.3 & 102.6 & 10.6 & 9.6 & 10.1 & 5.2 & 5.03 & 5.12 & 4.45 & 3.77 & 4.11 & 35.2 & 36.06 & 35.63 \\
\hline Maaroof & 105.9 & 114.3 & 110.1 & 10.7 & 11.3 & 11.0 & 6.8 & 6.23 & 6.52 & 4.61 & 4.73 & 4.67 & 37.53 & 40.45 & 38.99 \\
\hline Alwand & 94.1 & 108.0 & 101.1 & 11.6 & 13.6 & 12.6 & 6.4 & 5.90 & 6.15 & 3.84 & 3.50 & 3.67 & 40.56 & 42.13 & 41.35 \\
\hline Charmo & 104.6 & 112.3 & 108.5 & 11.9 & 12.3 & 12.1 & 5.8 & 6.37 & 6.08 & 4.80 & 5.00 & 4.90 & 43.67 & 45.23 & 44.45 \\
\hline Adana & 97.22 & 105.6 & 101.4 & 10.0 & 10.3 & 10.15 & 5.6 & 6.5 & 6.05 & 3.45 & 3.46 & 3.46 & 36.30 & 38.21 & 37.25 \\
\hline Aras & 98.4 & 93.0 & 95.7 & 9.1 & 8.5 & 8.80 & 6.8 & 7.17 & 6.98 & 3.01 & 2.83 & 2.92 & 34.53 & 32.27 & 33.40 \\
\hline Mean & 88.20 & 104.5 & 101.6 & 10.68 & 10.6 & 10.68 & 6.02 & 5.81 & 5.91 & 4.04 & 3.95 & 4.00 & 38.84 & 40.87 & 39.87 \\
\hline LSD 0.05 & 3.06 & 3.95 & 3.45 & 0.63 & 0.91 & 0.74 & 0.28 & 0.31 & 0.29 & 0.17 & 0.15 & 0.16 & 3.15 & 3.32 & 3.22 \\
\hline
\end{tabular}

\section{Grain Yield and yield components}

Results of Table 5 represent the means of grain yield and yield components of the studied genotypes, the variance analysis of the collected data shows the presence of significant differences between the genotypes in the mean of kernels weight per spike, the maximum kernel weight was observed in Charmo $(1.89 \mathrm{~g})$ which significantly exceed all other genotypes followed by Azmar2 (174g) and Shahoo2 (148g), while the lowest spike kernels weight was recorded in cv Aras (1.18g).
Grain weight per spike is considered as an important parameter for increasing grain yield; most of the recent released high yields potential cultivars characterized with high grain weight per spike. Significant effect of the genotypes in thousand-grain weight were also detected; Azmar 2 (45.67g) significantly surpassed other genotypes except HSAD, Bakrajo and Araz with means of 45.19, 44.90 and 44.42g respectively. Thousand-grain weight is related with biotic and abiotic stresses (Blum, 1998). Early sowing also greatly 
increases the weight of 1000-grains, while late sowing decreases the grain weight (Khan et al., 2001).

Results also showed that there were significant differences among the tested cultivars in the number of grain per spike; the highest grain numbers (57.49) was detected in Charmo, which was significantly surpassed all other cultivars followed by Azmar 2 and Alwand with 49.11 and 48.40 respectively, while the lowest number of grain was given by Bakrajo 139 and Aras (32,76 and 33.40 grain/spike) respectively (Table 4).

The number of spikes kernels is one of the most important yield components. That is why any change in this value will directly affect the grain yield of the cultivar (Rajaram et al., 1996). Many biotic and abiotic factors may decrease the number of grains per spike; the higher seed rate may also result from low spike kernels (Al-Maaroof et al. 2001).

Significant differences were found among the cultivars in number of spike per meter square (Table 5), The highest number of spikes per meter square (693) was detected in wheat cultivar Shaho2, which was significantly higher than all other cultivars followed by Alaa with 666 spike in each meter square. While the lowest number of spike per unit area was produced by Azmar2 (505/m²) and Bakrajo139 (517).

Spike number per unit area depends on the cultivars and environment and is strongly influenced by seed rate and plant density, the high temperature increases the rapid development of the plant and low production of tiller number/plant (Loveras et al., 2004).

Results of Table 5 demonstrate the presence of significant variation among the genotypes in grain yield per hectare. Charmo out yielded all other genotypes with $3542.46 \mathrm{~kg} / \mathrm{ha}$ and significantly surpassed all of other cultivars except Alaa that produce $3378.36 \mathrm{~kg} / \mathrm{ha}$ in 2016 , while the lowest yields were produced by the genotypes Aras and Bakrajo 139 with 2573.63 and $2837.49 \mathrm{~kg} / \mathrm{ha}$. respectively.

Table 5. Grain yield and yield component traits of some promising wheat genotypes comparing with the local cultivar at College of Agricultural Engineering Sciences, Bakrajo, University of Sulaimani, IKR, Iraq during 2015-2016.

\begin{tabular}{|c|c|c|c|c|c|c|c|c|c|c|c|c|c|c|c|}
\hline \multirow[t]{2}{*}{ Genotype } & \multicolumn{3}{|c|}{ Grain weight /spike (g) } & \multicolumn{3}{|c|}{1000 grain weight $(\mathrm{g})$} & \multicolumn{3}{|c|}{ Number of grains/spike } & \multicolumn{3}{|c|}{ Number of spike/m2 } & \multicolumn{3}{|c|}{$\begin{array}{c}\text { Grain yield/Ha } \\
(\mathrm{kg})\end{array}$} \\
\hline & 2015 & 2016 & Mean & 2015 & 2016 & Mean & 2015 & 2016 & Mean & 2015 & 2016 & Mean & 2015 & 2016 & Mean \\
\hline HSAD & 1.96 & 1.43 & 1.70 & 42.53 & 45.19 & 43.86 & 46.74 & 39.19 & 42.97 & 451.7 & 630.3 & 541.0 & 4198.23 & 3317.35 & 3757.79 \\
\hline Bakrajo139 & 1.51 & 1.22 & 1.37 & 40.46 & 44.90 & 42.68 & 43.91 & 32.76 & 38.34 & 472.3 & 517.0 & 494.65 & 3387.45 & 2837.49 & 3112.47 \\
\hline Shaho 2 & 1.55 & 1.48 & 1.52 & 47.30 & 43.62 & 45.46 & 49.34 & 38.70 & 44.02 & 479.5 & 693.7 & 586.6 & 3956.31 & 3283.77 & 3620.04 \\
\hline Azmar2 & 2.13 & 1.74 & 1.94 & 47.54 & 45.64 & 46.59 & 60.35 & 49.11 & 54.73 & 438.5 & 505.3 & 471.9 & 4023.52 & 3245.73 & 3634.63 \\
\hline Alaa & 1.85 & 1.33 & 1.59 & 44.65 & 43.56 & 44.11 & 55.50 & 41.01 & 48.26 & 443.0 & 666.5 & 554.75 & 4226.82 & 3378.36 & 3802.59 \\
\hline Maaroof & 1.89 & 1.44 & 1.67 & 41.36 & 42.74 & 42.05 & 52.75 & 45.77 & 49.26 & 491.3 & 645.3 & 568.3 & 3989.31 & 3169.55 & 3579.43 \\
\hline Alwand & 2.04 & 1.45 & 1.75 & 43.76 & 41.70 & 42.73 & 51.62 & 48.40 & 50.01 & 468.0 & 582.0 & 525.0 & 3785.90 & 3036.97 & 3411.44 \\
\hline Charmo & 2.21 & 1.89 & 2.05 & 45.33 & 43.22 & 44.27 & 59.33 & 57.49 & 58.41 & 461.0 & 532.5 & 496.75 & 4169.65 & 3542.46 & 3856.06 \\
\hline Adana & 1.50 & 1.40 & 1.45 & 41.51 & 38.38 & 39.95 & 45.30 & 38.33 & 41.82 & 423.5 & 604.3 & 513.9 & 3890.75 & 3112.53 & 3501.64 \\
\hline Aras & 1.34 & 1.18 & 1.26 & 40.32 & 44.42 & 42.37 & 42.53 & 33.40 & 37.97 & 459.5 & 640.6 & 550.05 & 3564.62 & 2573.63 & 3069.13 \\
\hline Mean & 1.79 & 1.46 & 1.63 & 43.48 & 43.38 & 43.52 & 50.74 & 42.42 & 46.58 & 458.83 & 601.75 & 530.29 & 3919.26 & 3149.78 & 3534.52 \\
\hline LSD 0.05 & 0.13 & 0.09 & 0.10 & 1.52 & 1.37 & 1.45 & 3.10 & 2.31 & 2.64 & 19.7 & 23.5 & 21.35 & 187.8 & 218.4 & 203.17 \\
\hline
\end{tabular}

\section{DISCUSSION}

The differences in the genetic background of resistance reflect the differences between the type of infection and the disease. The infection type in some cultivars may change over time due to the appearance of new virulence in the pathogen population. Some cultivars may remain resistant for a long time, but it become susceptible after a period of time. Al-Maaroof (1997) reported that Al-Eze infection type was moderately resistant at the time of release in 1995 while the same cultivar infection type changed to susceptible after a decade (Al-Maaroof and Asoda 2018). This shows the pathogen's ability to transform itself in to new virulence's and more aggressive genotypes that may occur by sexual reproduction, recombination, crossing over and other mechanisms that the pathogen could develop itself, it is therefore very important to monitor and study the population of the pathogen every year to recognize the new virulences that may come from other countries especially the disease is air borne, which has made it very difficult to control, and may overcome the resistance of some cultivars after release as resistant cultivars as it evident in the boom and burst cycle (Roelfs et al., 1992). This fact has been confirmed by many researchers (Luo and Zing 1995, Agrios, 2005). They referred to the ability of rust pathogens to develop themselves and produce new races that were not be founded before. The resistant reaction of Maaroof, Shaho2 and Azmar2 may be due to the presence of more than one resistant genes in their genetic back grounds which are absent in other susceptible cultivars. Possessing of more than one resistant gen increase duration of resistance stability in each cultivar, also the pathogen needs more time to develop virulence against the resistant gens, as it is mentioned by Markell and Milus (2008) and Messmer et al. (2000). The high infection of yellow rust disease on the susceptible wheat cultivars at both season may be due to the favorable environmental conditions and the amount of rainfalls at the test location (Table 2). 
The highest spike length value in these genotypes may be related to the high value of flag leaf area's in both genotypes (Table 4), Dry matter accumulation through photosynthesis will affect spike expansion. This result confirmed the findings of Aliu and Fetahu (2010). The mean highest value of awn length was detected in the local cultivar Aras (6.98) and significantly exceed all other cultivars followed by Maaroof $(6.52 \mathrm{~cm})$ and Alwand $(6.15 \mathrm{~cm})$, while the lowest value of awn length (5.12) was detected in Alaa.

Significant differences were observed among the cultivars in the mean of stem width values (Table 4), which were ranged from $2.92 \mathrm{~cm}$ in the local wheat cultivar Aras to $4.9 \mathrm{~cm}$ in Charmo. Charmo significantly surpassed all other cultivars followed by Maaroof $(4.67 \mathrm{~cm})$. Stem width and strength are directly related with lodging particularly in the irrigated areas. Lodging can reduce wheat grain yield by $7-80 \%$ (Berry and Spink, 2012), and may also result in decreasing grain quality, greater drying costs and slower harvest (Berry et al., 2004).

The results of Table 4 shows that there were large significant differences among the genotypes in the average area values of flag leaf. Azmar2 significantly surpassed all other genotypes for flag leaf area with $48.51 \mathrm{~cm} 2$ followed by Charmo and Shaho2 (44.45, $44.28 \mathrm{~cm} 2$, respectively), while the lowest value was detected in Aras $(33.40 \mathrm{~cm} 2)$. Flag leaf area is the most important trait since it provides the maximum amount of photosynthesis assimilates to be stored in the grains. Larger flag leaf area will eventually increase photosynthetic efficiency and grain filling period (Riaz and Chowdery, 2003). Flag leaf is considered as important selection criteria for high grain yields due to its short distance from the spike and staying green for a long time than other leaves (Khaliq et al., 2008).

The high grain yield potential of Charmo $(3542.46 \mathrm{~kg} / \mathrm{ha})$ is mainly attributed to the high number of grains per spike (57.49), while in Shaho2 and Alaa is due to the high number of spikes in meter square (693 and 666 respectively) and in HSAD is due to the high grain weight and number of spike per meter square (45.19 and 630), and Azmar2 is due to the high grain weight and number of grain per spike (45.64 and 49.11).

Grain yield is a complex trait which depends on large number of morphological, physiological, and environmental factors (Alam et al., 2007). The number of kernels per unit area and the individual kernel weight could determine strongly the grain yield. Differences in grain yield among the genotypes are depending on the yield potential of each genotype.

\section{V.CONCLUSION}

It could be concluded that high significant differences were detected between the assessed cultivars in their response to the growing seasons that was reflected by the variation in the agronomic and yield component traits. Performance of all the promising rust resistant wheat cultivars were good under rain fed conditions at Sulaimani and significantly surpassed the local wheat cultivar Aras, SaberBeg and Adana in most of the agronomic traits. All the promising rust resistant wheat cultivars significantly surpassed the local wheat cultivars Aras in yield and yield component traits except number of spike per meter square. Charmo is out yielded and significantly surpassed all other genotypes except Alla, and followed by Hasad and Shaho2. The high grain yield potential of Charmo is mainly due to the high number of grains per spike, while in Shaho2 due to the high number of spike per unit area.

It is recommended that providing the local farmers with the promising rust resistant genotypes for their high grain yield potential and resistance to rust diseases would highly reduce the amount of losses due to the disease and low productive genotypes in Kurdistan Region of Iraq. Evaluation performance of these genotypes under different agro ecological locations and seasons to determine the genetic stability of the tested genotypes to the fluctuated environmental conditions will assist in releasing the best cultivars for each specified environmental condition to escape heavy yield losses.

\section{REFERENCES}

Ahmad, N.S., Kareem, S.H., Mustafa, K.M. and Ahmad, D.A. (2017). Early screening of some Kurdistan wheat (Triticum aestivum L.) cultivars under drought stress. Journal of Agricultural Science, 9(2), pp.88-103.

Agrios G N. (2005). Plant Pathology, $5^{\text {th }}$ edition. Academic press. New York, 922p.

Alam, M.Z, Haider, S.A. Paul, N.K. (2007). Yield and yield components of Barely (Hordeum vulgaris L.) cultivars in relation to nitrogen. Fertilizer of Applied Research, 3: 1022-1026.

Al-Baldawi A.A. (1993). Occurrence and importance of wheat and barley Diseases in Iraq. Proceedings of Technology Transfer in the Production of Cereals and Legumes Workshop. pp 105-113. September 20, 1993, Mosul, Iraq,

Aliu, S., Fetahu, S. (2010). Determination on Genetic Variation for Morphological Traits and Yield Components of New Winter Wheat (Triticum aestivum L) Lines. Notulae Scientia Biologicae, 2: 121-124.

Al-Maaroof E.M. (1997). The role of variety mixtures in disease control of wheat rusts caused by Puccinia recondita and P. striiformis in Iraq. $\mathrm{Ph} . \mathrm{D}$ thesis, university of agriculture, Baghdad. Pp.132.

Al-Maaroof E.M, Ibrahim, I.F., Aboud A.R. (2001). Effect of leaf rust disease (Puccinia recondita Rob ex Desm tritici) on different wheat cultivars and genotypes in Iraq. Dirasat Journal for Agriculture Science, 28: 111120.

Al-Maaroof E.M., Singh R.P., Huerta J., Rattu A. (2005). Resistance of some Iraqi bread wheat cultivars to Puccinia triticina. Phytopatholgia Mediterrania 44: 247-255.

Al-Maaroof E.M., Nori A.M. (2018). Yellow rust development on different wheat genotypes. Journal of Zankoy Sulaimani Part-A, Special issue, $2^{\text {nd }}$ International Conf. of Agric. Sciences: 177-188.

Ali, S.H., Ahmad, N., Ahmad, M., Ahmad, D. (2018). Performance of Bread Wheat (Triticum aestivum L.) Varieties under Rainfed Condition of Sulaimani, Journal of Zankoy Sulaimani, 20: 29-36

Bell, M.A., Fischer, R.A. (1994). Guide to plant and crop sampling: measurements and observations for agronomic and physiological research in small grain cereals. vi, 66 pages. Mexico. CIMMYT. Series: CIMMYT Wheat Special Report (WPSR).

Berry, P.M., Spink, J. (2012). Predicting yield losses caused by lodging in wheat. Field Crops Research, 137: 19-26.

Berry, P.M., Sterling, M., Spink, J., Ennos, R. (2004). Understanding and Reducing Lodging in Cereals. Advances in Agronomy, 84: 217-271.

Blum, A. (1998). Improving wheat grain filling under stress by stem reserve mobilization. Euphytica, 100: 77-83.

Chanda, S.V., Singh, Y.D. (2002). Estimation of leaf area in wheat using linear measurements. Plant Breeding and Seed Science, 46: 75-79. 
FAO. (2018). World food and agriculture, statistical pocket book 2018. Food and Agriculture Organization of the United Nations. Rome 254pp.

FAO. (2003). Food and Agriculture Organization of the United Nations Viale delle Terme di Caracalla, 00100 Rome, Italy (2003).

Hawkesford, M.J., Araus, J.L., Park, R., Calderini, D., Miralles, D., Shen, T., Zhang, J., Parry, M.A. (2013). Prospects of doubling global wheat yields. Food and Energy Security, 2: 34-48.

Khaliq, I., Irshad, A., Ahsan, M. (2008). Awns and flag leaf contribution toward grain yield in spring wheat (Triticum aestivum). Cereal Research Communications, 36: 65-76.

Khan, M.A., Hussien, I., Baloch, M.S., Sayal, O. (2001). Evaluation of wheat varieties for grain yield in DI Khan. Sarhad Journal of Agriculture, 17: 41-46.

Lewellen, R., Sharp, E., Hehn, E. (1967). Major and minor genes in the wheat for resistance of Puccinia striiformis and their response to temperature changes. Canadian Journal of Botany, 45: 2155-2172.

Loveras, J., Manent, J., Viudas, J., Lopez, A., Santiveri, P. (2004). Seeding rate influence on yield and yield component of irrigated winter wheat in a Mediterranean climate. Agro J 96, 1258-1265.

Luo, Y., Zeng, Z. (1995). Simulation studies on epidemics of wheat stripe rust (Puccinia striiformis) on slow-rusting cultivars and analysis of effects of resistance components. Plant Pathology, 44: 340- 349.

MacRitchie, F. (1987). Evaluation of contributions from wheat protein fractions to dough mixing and bread making. Cereal Science 6: 259-268.

Markell, S.G. and Milus E.A. (2008). Emergence of a novel population of Puccinia f. sp. tritici in eastern United States. Phytopathology, 98:632639.

Messmer, M., Seyfarth, R., Keller, M., Schachermayr, G., Winzeler, M., Zanetti, S., Keller, B. (2000). Genetic analysis of durable leaf rust resistance in winter wheat. Theoretical Applied Genetics, 100: 419-431.

Peterson, R.F., Campbell, A.B., Hanna. (1949). A diagrammatic scale for estimating rust severity on leaves and stems of cereal. Canadian Journal of Research Sec., C 26: 249-500.

Rajaram, S., Braun, H., VanGingle, M. (1996). CIMMYT, Approach to breed for drought tolerance. Euphytica, 92: 147-153.

Reza, M. Amri, A. (2013). Phenotypic diversity and relationships among worldwide durum wheat germplasm collection under rain fed conditions of Iran. Crop and Pasture Science, 64: 87-99.

Riaz, R., Chowdery, M.A. (2003). Genetic analysis of some agronomic traits of wheat under drought conditions. Asian Journal of Plant Science, 2: 790-796.

Roelfs, A.P, Singh, R.P., Saari, E.E. (1992). Rust disease of wheat, Concepts and methods of disease management. Mexico, D.F: CIMMYT.P81.

Schnepf, R. (2003). Analyst in Agricultural Policy Resources, Science, and Industry Division; Iraq's Agriculture: Background and Status; RS21516 May 13, 2003. 